ROZ D Z I A E 9 .

\title{
ANALIZA ZMIAN UŻYTKOWANIA GRUNTÓW ROLNYCH W POLSCE PO 1990 ROKU
}

\author{
Barbara Roszkowska-Mądra ${ }^{1}$
}

\section{Wstęp}

Ziemia, obok kapitału i pracy, stanowi istotny czynnik produkcji, niezbędny w każdej działalności człowieka. Osobliwość tego czynnika przejawia się w jego ograniczoności i niemobilności. Ziemia jest dobrem wielofunkcyjnym, zaspokajającym wiele potrzeb i może być wykorzystywana do różnych celów gospodarczych. Między niektórymi z tych celów występują wyraźne konflikty. W Polsce rolnictwo jest dominującym sposobem użytkowania ziemi. Do 1990 roku całość zasobów ziemi rolniczej była zaangażowana w proces produkcji rolnej. Po roku 1990 sytuacja w tym zakresie znacząco uległa zmianie. Od tego czasu obserwuje się sukcesywny spadek powierzchni gleb użytkowanych rolniczo. W początkowym okresie gospodarki rynkowej był on spowodowany przyjęciem koncepcji transformacji systemowej według modelu tzw. terapii szokowej, co skutkowało nieefektywnym wykorzystaniem czynników produkcji w rolnictwie, w tym czynnika ziemi rolniczej, a to sprzyjało spadkowi powierzchni użytków rolnych i wzrostowi powierzchni odłogowanych

${ }^{1}$ Dr hab. Barbara Roszkowska-Mądra, prof. UwB, Uniwersytet w Białymstoku. 
i ugorowanych gruntów ornych. Przystąpienie Polski do struktur Unii Europejskiej również sprzyjało przejmowaniu gruntów rolnych na inne cele niż rolne i leśne. W dalszym ciągu obserwuje się sukcesywny spadek powierzchni gleb użytkowanych rolniczo i jest to związane z przeznaczaniem ich na cele pozarolnicze - urbanizację, transport ${ }^{2}$. Ten niepokojący proces w ostatnich latach obejmuje także w dużej mierze gleby bardzo dobre i dobre. Stwarza on niemałe zagrożenia dla produkcyjności polskiego rolnictwa, ponieważ dla realizacji celów produkcyjno-ekonomicznych rolnictwa istotne znaczenie mają dobre gleby.

Celem niniejszego rozdziału jest charakterystyka zjawisk i rozwiązań prawnych w Polsce po 1990 roku, dotyczących zmian powierzchni i użytkowania gruntów rolnych. W szczególności, rozpatrywane są a) przyczyny spadku powierzchni gruntów rolnych, b) tempo przeznaczania powierzchni gruntów rolnych na cele nierolnicze, c) ocena rozwiązań prawnych, służących ochronie gruntów rolnych w Polsce i w ramach polityki Unii Europejskiej, wspierających zachowanie użytkowania rolniczego na gruntach rolnych.

\subsection{Charakterystyka rolniczej przestrzeni produkcyjnej}

Użytki rolne określające ramy działalności rolnictwa decydują o jego potencjale produkcyjnym, kierunkach produkcji, w tym produkcji roślinnej i zwierzęcej. W Polsce powierzchnia gleb użytkowanych rolniczo zmniejsza się w związku z przeznaczaniem znacznych terenów na cele pozarolnicze - urbanizację, transport ${ }^{3}$. Procesy te dotyczą również gleb bardzo dobrych i dobrych, co stwarza zagrożenia dla produkcyjności polskiego rolnictwa.

${ }^{2}$ A. Wasilewski, Zmiany zasobu użytków rolnych $w$ Polsce, „Roczniki Naukowe SERiA" 2007, nr 9(1), s. 508-512.

${ }^{3}$ Tamże, s. 508-512. 
Powierzchnia gruntów rolnych w Polsce wynosi 18,6 mln ha, co stanowi 59,8\% powierzchni kraju. Na 1 mieszkańca przypada 0,49 ha z utrzymującą się tendencją malejącą w tym zakresie. W 2017 roku powierzchnia użytków rolnych w gospodarstwach rolnych wyniosła 14,5 mln ha, co stanowi 89,2\% powierzchni ogólnej gospodarstw rolnych. Użytki rolne w dobrej kulturze rolnej zajmowały 99,0\% ogólnej powierzchni użytków rolnych, zaś grunty ugorowane $0,9 \%$, natomiast powierzchnia gruntów ornych wynosiła 10,7 mln ha, co stanowi 72,6\% udziału gruntów ornych w powierzchni użytków rolnych ${ }^{4}$.

Jakość gleb jest jednym z czynników w największym stopniu wpływających na możliwości uzyskiwania wysokich dochodów z prowadzonej produkcji rolniczej. Czynnik ten jest niezależny od pozostałych elementów wpływających na dochodowość produkcji rolniczej, takich jak rozdrobnienie działek, struktura obszarowa gospodarstw czy uwarunkowania ekonomiczne. Jakość polskich gleb należy do najniższych w Europie. Potencjał produkcyjny przeciętnego hektara gleb w Polsce odpowiada potencjałowi przeciętnych 0,6 ha gruntów ornych krajów Unii Europejskiej. Wynika to głównie z faktu, że w ogólnej powierzchni polskich gruntów ornych znajduje się prawie 32\% gruntów słabych i bardzo słabych, a tylko około 29\% gleb wysokiej produktywności ${ }^{5}$.

Klasyfikacja gruntów w Polsce jest wykonywana na podstawie ustawy z dnia 17 maja 1989 r. - Prawo geodezyjne i kartograficzne i przepisów wykonawczych do tej ustawy. Do 28 listopada 2012 roku klasyfikacji dokonywało się na podstawie dekretu z dnia 2 lutego 1955 r. o ewidencji gruntów i budynków. W dniu 29 listopada 2012 roku weszło w życie rozporządzenie Rady Ministrów z dnia 12 września 2012 r. w sprawie gleboznawczej klasyfikacji gruntów (Dz.U. z 2012. r., poz. 1246). Do szacunkowego określenia możliwości produkcyjnych gleby pod względem jej

\footnotetext{
${ }^{4}$ Rocznik Statystyczny Rolnictwa 2018, GUS, Warszawa 2019.

${ }^{5}$ P. Skłodowski, A. Bielska, Wtaściwości i urodzajność gleb Polski podstawą ksztattowania relacji rolnośrodowiskowych, „Woda - Środowisko - Obszary Wiejskie” 2009 , t. 9 , z. $4(28)$, s. 203-214.
} 
wartości użytkowej, czyli jakości, wykorzystywana jest bonitacja gleb, którą wyraża się w klasach lub punktach. Przy tworzeniu klas bonitacyjnych bierze się pod uwagę: żyzność gleby, stosunki wodne w glebie, stopień kultury gleby i trudność uprawy w powiązaniu z agroklimatem, rzeźbą terenu oraz niektórymi elementami stosunków gospodarczych. W Polsce gleby najlepsze i bardzo dobre I i II klasy bonitacyjnej stanowią zaledwie $3,3 \%$ użytków rolnych, gleby dobre i średnio dobre (IIIa i IIIb) - 22,7\% użytków rolnych, a słabe, bardzo słabe i złe (V i VI klasa bonitacyjna) 34\% użytków rolnych.

Wskaźnik bonitacji gleb, określający ich jakość w gospodarstwie umożliwia przeliczanie hektarów fizycznych na przeliczeniowe, które są zróżnicowane według okręgów podatkowych i stanowią podstawę wymiaru podatku rolnego ${ }^{6}$.

W Polsce występuje duże zróżnicowanie potencjału rolniczej przestrzeni produkcyjnej. Wynika ono z przestrzennej zmienności pokrywy glebowej, ukształtowania terenu oraz opadów i temperatury. Średnia wartość wskaźnika waloryzacji rolniczej przestrzeni produkcyjnej (WWRPP) dla Polski wynosi 66,6 punktów. Na zróżnicowanie wskaźnika waloryzacji najsilniej wpływa ziemia ${ }^{7}$.

\subsection{Zmiany w rolniczym użytkowaniu gruntów po 1990 roku}

Na przestrzeni blisko trzydziestu lat (1990-2017) w użytkowaniu gruntów zaszły istotne zmiany, polegające na systematycznym spadku powierzchni użytków rolnych o 21,1\%, w tym gruntów ornych o 24,8\%, co ilustruje tabela 9.1. oraz wykres 9.1.

${ }^{6}$ Ustawa z dnia 15 listopada 1984 r. o podatku rolnym, Dz.U. z 2016 r., poz. 617.

${ }^{7}$ S. Krasowicz i in., Racjonalne gospodarowanie środowiskiem glebowym Polski, "Polish Journal of Agronomy" 2011, nr 7, s. 43-58; S. Krasowicz., Problemy zrównoważonego rozwoju rolnictwa polskiego $w$ świetle badań IUNG-PIB, „Studia i Raporty IUNiG-PIB” 2012, z. 29(3), s. 21-47. 
Tabela 9.1. Użytkowanie gruntów w Polsce w latach 1990-2017 (w tys. ha)

\begin{tabular}{lccccccc}
\hline & 1990 & 1995 & 2000 & 2005 & 2010 & 2015 & 2017 \\
\hline \hline \multicolumn{7}{c}{ Użytki rolne } \\
\hline \hline Razem & 18539 & 17934 & 17812 & 15906 & 15503 & 14545 & 14620 \\
\hline $\begin{array}{l}\text { Grunty } \\
\text { orne }\end{array}$ & 14311 & 13886 & 13684 & 12222 & 10946 & 10753 & 10757 \\
\hline Sady & 268,8 & 278,6 & 256,7 & 296,5 & 374,2 & 350,0 & 362,0 \\
\hline tąki & 2426,7 & 2272,2 & 2502,8 & 2529,2 & 2629,2 & 2658,1 & 2795,8 \\
\hline Pastwiska & 1532,6 & 1497,7 & 1369,3 & 858,3 & 654,3 & 434,7 & 374,9 \\
\hline Pozostałe & 0,0 & 0,0 & 0,0 & 0,0 & 899,7 & 147,1 & 147,1 \\
\hline \hline $\begin{array}{l}\text { Lasy } \\
\text { i grunty leśne }\end{array}$ & 8754,0 & 8821,8 & 9003,9 & 9172,6 & 9329,1 & 9343,8 & 9801,3 \\
\hline \hline $\begin{array}{l}\text { Pozostałe } \\
\text { grunty }\end{array}$ & 3975,2 & 4512,4 & 4452,3 & 6190,0 & 6435,9 & 8180,0 & 8143,7 \\
\hline
\end{tabular}

Źródło: dane GUS.

Rozpatrując użytki zielone, warto zwrócić uwagę na nieznaczny $(15,2 \%)$ wzrost powierzchni łąk i wyraźne (o 75,5\%) zmniejszenie powierzchni pastwisk. W ten sposób powierzchnia użytków rolnych w kraju spadła w 2017 roku do poziomu 46,6\%, zaś gruntów ornych do poziomu $34,2 \%$. Wskaźniki te są najniższymi w historii kraju i w analizowanym okresie. Należy zauważyć, że spadki te miały miejsce głównie do czasu przystąpienia Polski do struktur unijnych w 2004 roku, potem ubytek użytków rolnych, jak i gruntów ornych był już stosunkowo niewielki, odpowiednio $8,1 \%$ użytków rolnych i $12 \%$ gruntów ornych. W analizowanym okresie wzrosła powierzchnia pozostałych gruntów, pod pojęciem których mieszczą się tereny osiedlowe, komunikacyjne i drogowe, wody i inne obszary (użytki kopalne, nieużytki) i powierzchnia lasów i gruntów leśnych o blisko $12 \%$, co można wiązać z realizacją ustawy z dnia 
8 czerwca 2001 roku $^{8}$ o przeznaczaniu gruntów rolnych do zalesiania, po przystąpieniu Polski do struktur unijnych mechanizmów Wspólnej Polityki Rolnej (WPR; II filar WPR - programy rolnośrodowiskowe).

Trudna sytuacja ekonomiczna sektora rolnego, polegająca na jego marginalizacji w polityce gospodarczej naszego kraju w latach 1990$2001^{9}$, nie sprzyjała efektywnemu zagospodarowaniu ziemi. Konsekwencją tego stanu rzeczy był wzrost powierzchni odłogowanych i ugorowanych gruntów ornych w Polsce ${ }^{10}$, która w latach 1990-1995 wynosiła odpowiednio 1,63 $\mathrm{mln}$ ha i 1,32 $\mathrm{mln}$ ha (wykres 9.1.). Największa powierzchnia odłogowanych i ugorowanych gruntów ornych $(1,66 \mathrm{mln}$ ha) wystąpiła w 2000 roku. W późniejszym okresie można było zaobserwować obniżanie ich powierzchni, czemu sprzyjało zalesianie nieprzydatnych dla rolnictwa słabych użytków rolnych ${ }^{11}$. Najbardziej symptomatyczną oznaką zmian w sposobach użytkowania ziemi rolniczej w Polsce po jej akcesji do Unii Europejskiej, jest ogromne i bardzo dynamiczne zmniejszanie się obszaru odłogów. W 2004 roku odłogi obejmowały obszar prawie 1,4 mln hektarów, po czym ich powierzchnia spadła do 2010 roku do poziomu mniej niż jednej trzeciej stanu wyjściowego (449 tys. ha), ulegając w tym samym tempie dalszemu zmniejszeniu do 134 tys. ha

${ }^{8}$ Ustawa z dnia 8 czerwca 2001 r. o przeznaczaniu gruntów rolnych do zalesienia, Dz.U. z 2001 r. nr 73, poz. 764, z póź. zm.

${ }^{9}$ A. Czyżewski, Relacje między otoczeniem makroekonomicznym a rolnictwem $w$ okresie transformacji gospodarki Polski (1990-2009), „Roczniki Naukowe SERiA” 2010, t. XII, z. 1, s. 23-28.

${ }^{10}$ Do 2007 roku w statystyce krajowej używano pojęcia odłogi i ugory. Do odłogów zaliczano powierzchnię gruntów ornych, niedających plonów, które co najmniej przez dwa lata nie były uprawiane, natomiast do ugorów - powierzchnie, które w danym roku były przejściowo nieobsiane. Od 2007 roku wprowadzono pojęcie gruntów ugorowanych, do których zalicza się powierzchnię gruntów ornych, niewykorzystywanych do celów produkcyjnych, ale utrzymywanych według zasad dobrej kultury rolnej. Zob. rozporządzenie Ministra Rolnictwa i Rozwoju Wsi z dnia 12 marca 2007 r. w sprawie minimalnych norm, Dz.U. z 2007 r. nr 46, poz. 306.

${ }^{11}$ Ustawa z dnia 8 czerwca 2001 r. o przeznaczaniu gruntów rolnych do zalesienia, Dz.U. z 2001 r. nr 73, poz. 764, z późn. zm. 
w 2015 roku, a w 2016 roku 165 tys. ha, czyli do poziomu 10\% obszaru odłogów sprzed akcesji.

Wykres 9.1. Powierzchnia odłogów i ugorów (w tys. ha)

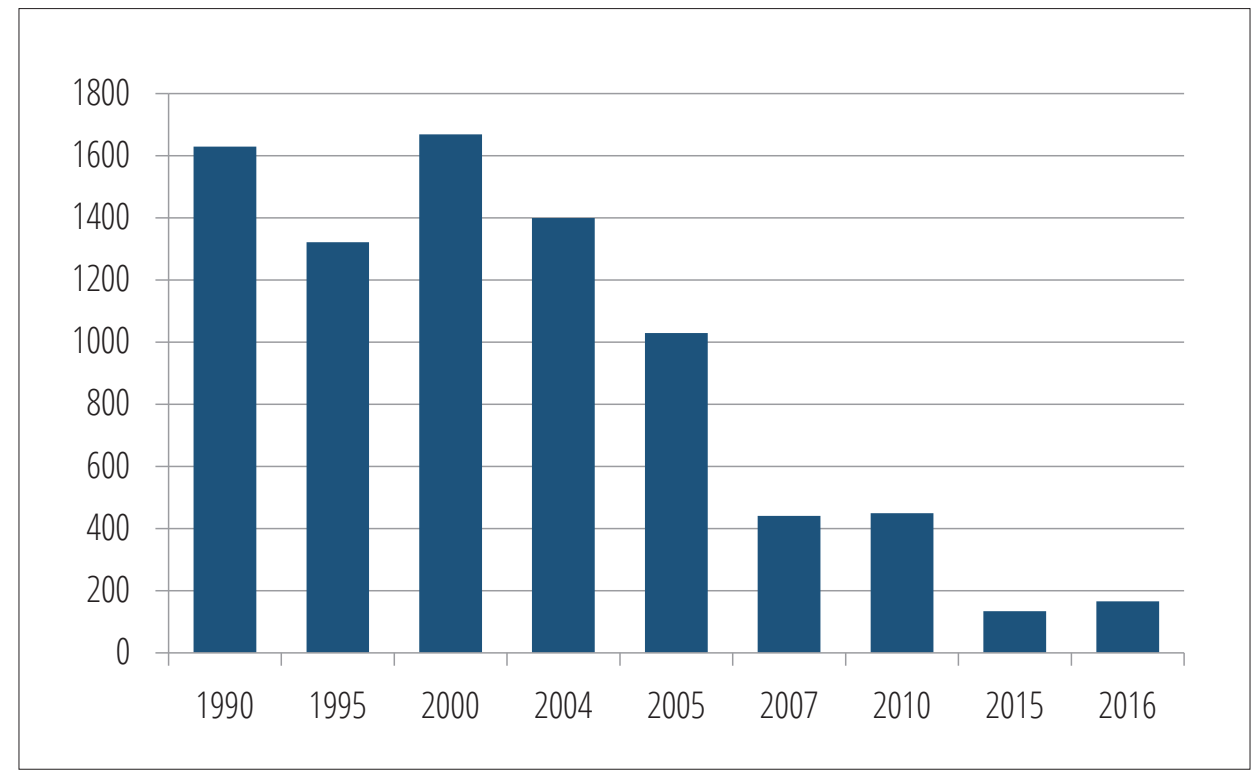

Źródło: opracowanie własne na podstawie: Ochrona środowiska, GUS, Warszawa 2016.

W latach 2004-2016 następowało systematyczne zmniejszanie się całkowitej powierzchni użytków rolnych od 16,3 mln ha w 2004 roku do 14,4 mln ha w 2016 roku. W podobnym tempie ubywało także trwałych użytków zielonych od 3,4 mln ha w 2004 roku do niespełna 3,1 $\mathrm{mln}$ ha w 2016 roku oraz ornych od 12,7 mln ha w 2004 do 10,7 mln ha w 2016 roku. Jednocześnie charakterystyczny dla tego okresu jest wzrost powierzchni gruntów rolnych przeznaczanych na cele nierolnicze.

\subsection{Grunty rolne wycofywane na cele nierolnicze}

Od początku transformacji ustrojowej w Polsce obserwuje się systematyczny spadek powierzchni gruntów rolnych. W głównej mierze jest to 
spowodowane wyłączaniem tych gruntów na cele nierolnicze. Największą powierzchnię, blisko 6 tys. ha gruntów rolnych wyłączono na cele nierolnicze w 1990 roku, co ilustruje wykres 9.2. Stało się to za przyczyną zliberalizowania przepisów prawnych chroniących grunty rolne i leśne na mocy ustawy o ochronie gruntów rolnych i leśnych z 1982 roku, a mianowicie w 1990 i 1991 roku uchylono obowiązek rolniczego wykorzystania gruntów rolnych i postanowienia dotyczące restrykcyjnych regulacji w stosunku do właścicieli odłogujących grunty rolne.

Zatem, w latach 1990-1994 wyłączano rocznie z użytkowania rolniczego, zgodnie z literą prawa, od 4 do 7 tys. ha gruntów. Były to lata, w których na cele nierolnicze i nieleśne przeznaczano najwięcej gruntów rolnych.

Wykres 9.2. Grunty rolne wyłączone na cele nierolnicze w Polsce w latach 1990-2015 (w ha)

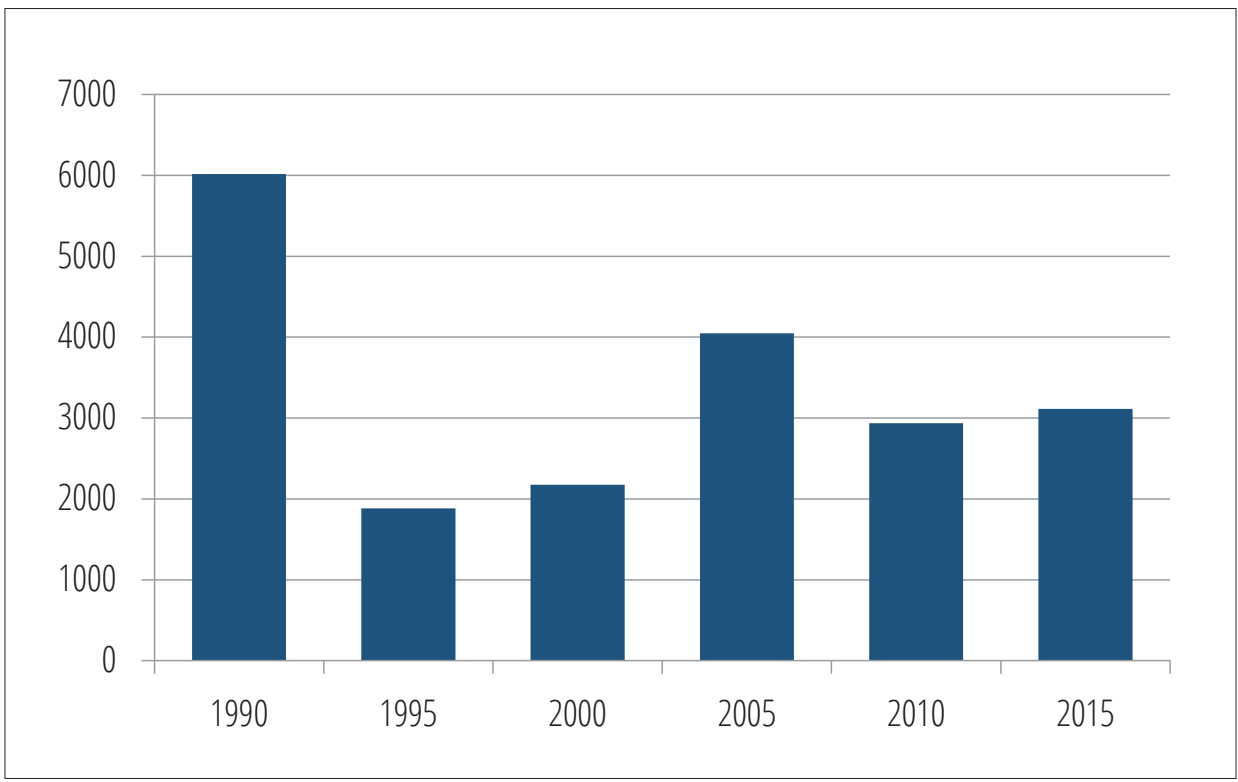

Źródło: opracowanie własne na podstawie: Ochrona środowiska, GUS, Warszawa 2016.

Od rozpoczęcia obowiązywania przepisów ustawy o ochronie gruntów rolnych i leśnych z 1995 roku do czasu przystąpienia Polski do Unii 
Europejskiej znacząco zmniejszyła się powierzchnia wyłączanych gruntów na cele nierolnicze i nieleśne. Rocznie wyłączano, zgodnie z obowiązującymi przepisami tej ustawy, od 1 tys. do 3 tys. ha. Powodem było rosnące zainteresowanie kupnem ziemi jako formy lokaty kapitału, często przez osoby w żaden sposób niezwiązane z rolnictwem, w celu jej dalszego wykorzystania jako przedmiotu transakcji w celach spekulacyjnych (sprzedaży, dzierżawy) ${ }^{12}$. Oczekiwano wzrostu cen ziemi po przystąpieniu Polski do struktur Unii Europejskiej. Ponadto, dla niektórych osób atrakcyjna stała się możliwość skorzystania z ubezpieczenia w Kasie Społecznego Ubezpieczenia Rolniczego (KRUS) ${ }^{13}$.

Jednakże, po akcesji Polski do struktur unijnych przyspieszony rozwój regionalny skutkował wzrostem powierzchni wyłączanych gruntów rolnych z użytkowania rolniczego. W 2005 roku wyłączono blisko dwukrotnie większą powierzchnię gruntów w stosunku do 1995 roku. W latach 2004-2008 wyłączano od ponad 3 tys. ha do 5 tys. ha rocznie na inne cele niż rolne lub leśne. Po 2008 roku, kiedy zaczęły być odczuwalne, także w polskiej gospodarce, symptomy globalnego kryzysu, zaobserwowano zmniejszenie ubytku gruntów rolnych na cele nierolnicze i nieleśne. W latach 2010-2017 wyłączono od 2 tys. ha do 4 tys. ha w 2017 roku.

${ }^{12}$ B. Roszkowska-Mądra, R. Przygodzka, A. Sadowski, A Range and Reasons of Farmland With-drawal from Agricultural use in Poland, „EU Agrarian Law: The Journal of Slovak University of Agriculture in Nitra" 2017, nr 1; A. Sadowski, R. Przygodzka, Economic Aspects of Land Management in the EU, [w:] The Land Management Manual of the EU, A. Bandlerová i in. (red.), Slovak University of Agriculture in Nitra, Nitra 2017; A. Sadowski, R. Przygodzka, Withdrawal of Agricultural Land in Select EU Countries: Case Poland, [w:] The Land Management Manual of the EU, A. Bandlerová i in. (red.), Slovak University of Agriculture in Nitra, Nitra 2017.

13 J. Szymańska, Ubytek ziemi rolniczej $w$ Polsce $w$ długim okresie (wybrane problemy), „Roczniki Ekonomiczne Kujawsko-Pomorskiej Szkoły Wyższej w Bydgoszczy” 2015, nr 8, s. 145-163. 
Dominującym kierunkiem wyłączania gruntów rolnych na cele nierolnicze w Polsce było i w dalszym ciągu jest przeznaczanie ich pod budownictwo osiedlowe, co ilustruje wykres 9.3. Dotyczy to głównie obszarów wiejskich położonych w bliskim sąsiedztwie dużych ośrodków miejskich ${ }^{14}$.

Wykres 9.3. Kierunki wyłączania gruntów rolnych na cele nierolnicze w Polsce w latach 1990-2015 (ha)

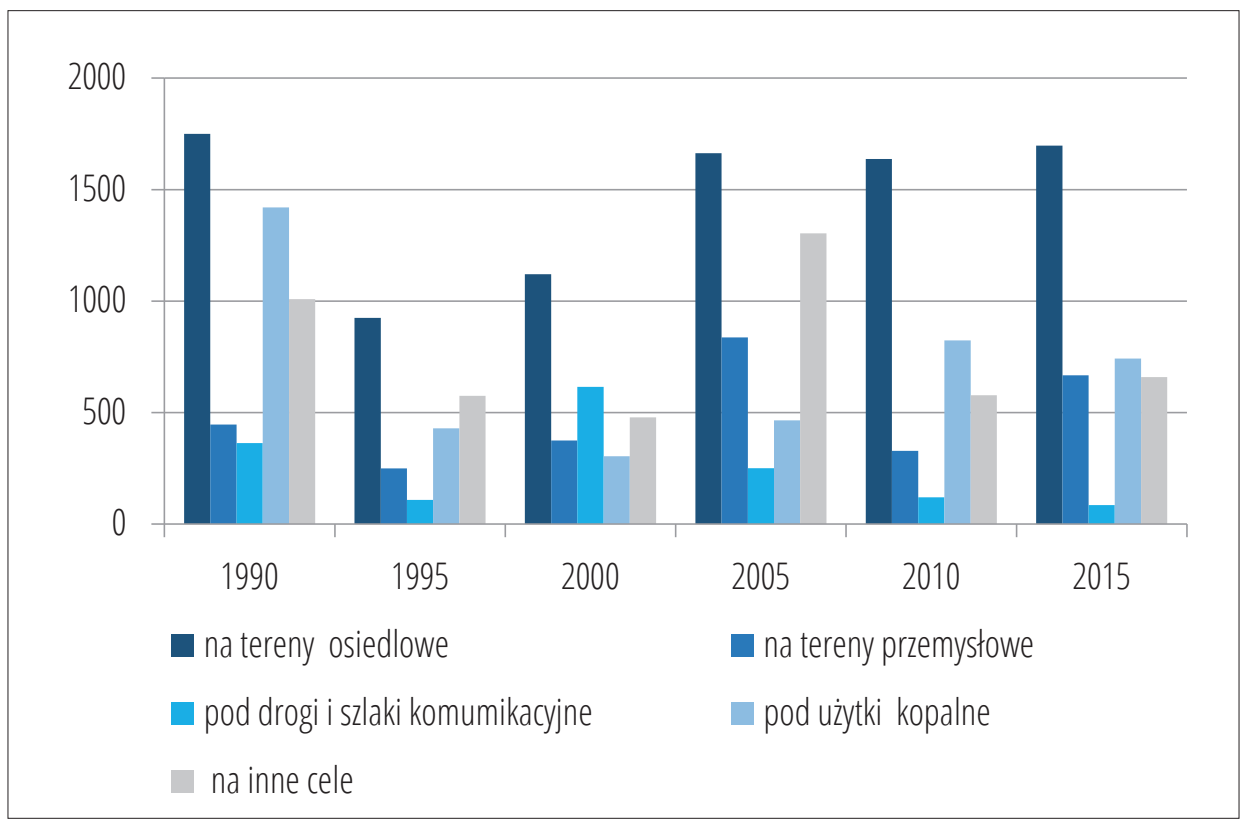

Źródło: opracowanie własne na podstawie: Ochrona środowiska, GUS, Warszawa 2016.

W 1990 roku pod tereny osiedlowe wyłączono 1750 ha gruntów rolnych, a pod użytki kopalne 1420 ha. W latach 1990-2008 na ten cel wyłączono z użytkowania rolniczego blisko 34 tys. ha użytków rolnych. W dalszym ciągu jest to główny kierunek wyłączania użytków rolnych

${ }^{14}$ E. Kacprzak, B. Mackiewicz, Farmland conversion and changes in the land-use pattern in the Poznan agglomeration in the years 2000-2009, "Questiones Geographicae" 2013, nr 32(4), s. 91-102. 
na cele nierolnicze. Ponadto, znaczne obszary ziemi rolnej wyłączane są na potrzeby przemysłu i pod użytki kopalne ${ }^{15}$.

Tabela 9.2. Powierzchnia użytków rolnych wyłączana na cele nierolnicze, według klas bonitacyjnych w Polsce w latach 1990-2017 (ha)

\begin{tabular}{lcccc}
\hline Lata & Razem & Klasa I-III & Klasa IV & Klasa V-VI \\
\hline \hline 1990 & 5936 & 1196 & 1617 & 3123 \\
\hline 1995 & 1419 & 876 & 431 & 112 \\
\hline 2000 & 1501 & 1053 & 393 & 55 \\
\hline 2005 & 2782 & 1783 & 858 & 141 \\
\hline 2010 & 1831 & 922 & 798 & 111 \\
\hline 2015 & 2308 & 1401 & 788 & 119 \\
\hline 2016 & 2967 & 1893 & 953 & 121 \\
\hline 2017 & 3004 & 1807 & 1073 & 124 \\
\hline Razem & 21748 & 10931 & 6911 & 3906 \\
\hline
\end{tabular}

Źródło: opracowanie własne na podstawie: Ochrona środowiska, GUS, Warszawa 2016.

Niepokojącym zjawiskiem w analizowanym okresie było wyłączanie z rolniczego użytkowania, gleb bardzo dobrych i dobrych (o wysokiej produktywności), które mają istotne znaczenie dla realizacji celów produkcyjno-ekonomicznych rolnictwa, zważywszy również i na to, że jakość polskich gleb należy do najniższych w Europie. W analizowanym okresie wyłączono z użytkowania rolniczego blisko 20 tys. hektarów użytków rolnych, przy czym 50\% stanowiły gleby bardzo dobre, co ilustruje tabela 9.2. i wykres 9.4.

${ }^{15}$ B. Roszkowska-Mądra, R. Przygodzka, A. Sadowski, A range and reasons of farmland withdrawal from agricultural use in Poland, "EU Agrarian Law" 2017, t. 6, nr 1, s. 37-42. 
Wykres 9.4. Powierzchnia użytków rolnych wyłączona na cele nierolnicze według klas bonitacyjnych w Polsce w latach 1990-2015 (ha)

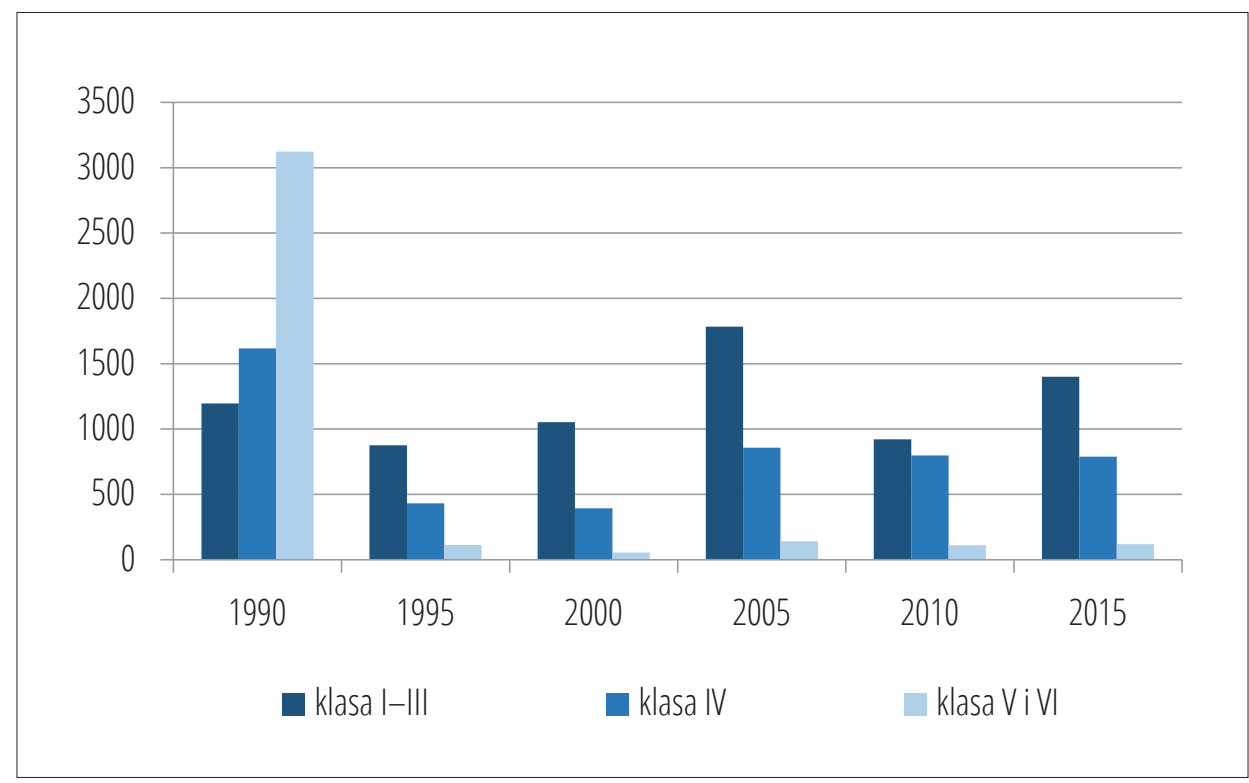

Źródło: opracowanie własne na podstawie: Ochrona środowiska, GUS, Warszawa 2016.

\subsection{Ochrona prawna gruntów rolnych w Polsce}

Grunty rolne należą do nieodnawianych zasobów środowiska naturalnego. Ze względu na swoją specyfikę i pełnione funkcje wymagają skutecznej i zrównoważonej ochrony prawnej. Pierwszym aktem prawnym poświęconym tematyce ochrony gruntów rolnych w Polsce była uchwała Rady Ministrów z dnia 12 lipca 1966 roku w sprawie użytków rolnych, w której przyjęto, że na cele niezwiązane z produkcją rolniczą należy przeznaczać przede wszystkim nieużytki oraz grunty najsłabszej jakości, tj. klas V i VI. Natomiast przeznaczanie użytków rolnych dobrej jakości (klas I-IV) mogło się odbywać wyłącznie w szczególnych okolicznościach ${ }^{16}$.

16 J. Górska, W. Michna, Ubytek użytków rolnych na cele pozarolnicze $w$ Polsce, „Wieś i Rolnictwo” 2010, nr 4(149), s. 57-74. 
W polskim ustawodawstwie kluczowe znaczenie ochronne odgrywa ustawa z dnia 3 lutego 1995 r. o ochronie gruntów rolnych i leśnych (tekst jednolity Dz. U. 2015 poz. 909 ze zm.). Jednak, co należy podkreślić, rozwiązania prawne tworzące współczesny polski system ochrony gruntów rolnych wykraczają daleko poza jej ramy. Regulacje ochronne można bowiem odnaleźć w aktach prawnych dotyczących m.in. zagospodarowania przestrzennego, regulacjach skupionych na ochronie środowiska i przyrody, a także w wyspecjalizowanych ustawach sektorowych związanych m.in. z funkcjonowaniem przemysłu wydobywczego, czy przeprowadzaniem strategicznych inwestycji państwowych.

Ustawa z 1995 roku o ochronie gruntów rolnych i leśnych obejmowała ochronę gruntów rolnych polegającą na ograniczaniu przeznaczania ich na cele nierolnicze oraz zapobieganiu procesom degradacji czy dewastacji, powstającym wskutek działalności nierolniczej. Procesy związane z industrializacją i koniecznością rozbudowy infrastruktury technicznej powodowały, że ustawa z 1995 roku była wielokrotnie nowelizowana. Ogólny kierunek zmian zmierzał do uwolnienia gruntów rolnych na cele nierolnicze i usunięcia barier administracyjnych, utrudniających zamierzenia inwestycyjne. Aczkolwiek, przy budowie, rozbudowie lub modernizacji obiektów związanych z działalnością przemysłową, należało stosować takie rozwiązania, które ograniczałyby ujemne skutki oddziaływania na grunty rolne. W przypadku przeznaczenia gruntów rolnych klas I-III na cele nierolnicze, zachodziła potrzeba uiszczenia należności i opłat rocznych. Ustawa chroniła także grunty rolne klas bonitacyjnych IV-VI, wytworzonych z gleb organicznych.

Od 2003 roku rozpoczęto sukcesywnie ograniczać ochronę gruntów rolnych. Była to konsekwencja wprowadzonej w 2003 roku ustawy o planowaniu i zagospodarowaniu przestrzennym ${ }^{17}$. Skutkowało to uchyleniem dotychczasowych miejscowych planów zagospodarowania przestrzennego, a w konsekwencji osłabieniem ochrony gruntów rolnych. Dalsze

${ }^{17}$ Ustawa z dnia 27 marca 2003 r. o planowaniu i zagospodarowaniu przestrzennym, Dz.U. z 2003 r. nr 80, poz. 717. 
osłabienie ochrony gruntów rolnych polegające na różnicowaniu reżimu ochrony gruntów rolnych w zależności od ich położenia, wprowadziła ustawa z dnia 19 grudnia 2008 r. o zmianie ustawy o ochronie gruntów rolnych i leśnych ${ }^{18}$. Ustawa zezwalała na przeznaczanie użytków rolnych (UR) położonych w granicach administracyjnych miast na cele nierolnicze z pominięciem obowiązku uzyskania zgody właściwego organu na zmianę ich przeznaczenia, uchwalania w tym celu miejscowego planu zagospodarowania oraz uiszczania stosownych opłat ${ }^{19}$. Wprowadzone zmiany ograniczyły możliwości ochrony gruntów o wysokiej przydatności produkcyjnej, spowodowały wzrost cen ziemi w pobliżu miast, rozszerzenie granic administracyjnych miast i rozproszenie zabudowy - jest to konsekwencja przeznaczania na cele urbanizacyjne w dokumentach planistycznych zbyt dużych, w stosunku do rzeczywiście niezbędnych, powierzchni pod zabudowę ${ }^{20}$.

W 2013 roku nastąpiły zmiany w ochronie gruntów rolnych ${ }^{21}$. Wprowadzona ustawa zniosła zapis zwalniający z ochrony grunty rolne klas I-III, jeżeli ich zwarty obszar na cele nierolnicze wynosił do 0,5 ha. Natomiast wszystkie grunty klas I-III położone poza granicami administracyjnymi miast wymagały zmiany w miejscowym planie oraz zgody właściwego ministra, jeżeli miały być przeznaczone na cele nierolnicze. Tym samym ochrona gruntów rolnych zwiększyła się ${ }^{22}$.

${ }^{18}$ Ustawa z dnia 19 grudnia 2008 r. o zmianie ustawy o ochronie gruntów rolnych i leśnych, Dz.U. z 2008 r. nr 237, poz. 1657.

19 T. Klusek, Uwarunkowania i skala wyłączania na cele nierolnicze gruntów o największej przydatności produkcyjnej, „Roczniki Naukowe SERiA” 2014, t. CVI, z. 6., s. 235-240.

${ }^{20}$ S. Krasowicz i in. dz. cyt., s. 43-58.

${ }^{21}$ Ustawa z dnia 8 marca 2013 r. o zmianie ustawy o ochronie gruntów rolnych i leśnych, Dz.U. z 2013 r., poz. 503.

22 A. Świtalska, Ochrona gruntów rolnych a planowanie przestrzenne od roku 1995 w Polsce, „Wędrujemy. Kwartalnik Naukowo-Dydaktyczny” 2016, nr 25, s. 241256. 
W 2015 roku podjęto nowe ustalenia ${ }^{23}$ częściowo znoszące ochronę gruntów cennych pod względem rolniczego zagospodarowania (klasa I-III), ograniczając wielkość obszaru niepodlegającego ochronie do 5 ha, jednak wprowadzając dodatkowe wymogi ${ }^{24}$.

W pewnym zakresie ochronę gruntów rolnych przed nierolniczym wykorzystaniem wprowadziła także ustawa z dnia 14 kwietnia 2016 r. o wstrzymaniu sprzedaży nieruchomości Zasobu Własności Rolnej Skarbu Państwa oraz o zmianie niektórych ustaw ${ }^{25}$.

\subsection{Polityka Unii Europejskiej w zakresie ochrony gruntów rolnych}

Przystąpienie Polski do Unii Europejskiej i powiązane z tym objęcie polskiego rolnictwa i obszarów wiejskich wspólną polityką rolną UE, przyczyniło się wyraźnienie do wzmocnienia ochrony gruntów rolnych przed ich nierolniczym wykorzystywaniem. W ramach I filara WPR stosowane są dopłaty bezpośrednie, które są najbardziej powszechną formą ochrony gruntów rolnych w polityce Unii Europejskiej, uzależniają otrzymanie wsparcia od spełniania wymogów wzajemnej zgodności (ang. cross compliance $)^{26}$. Beneficjent tej pomocy jest zobowiązany do przestrzegania wymogów podstawowych w zakresie zarządzania i zasad dobrej kultury rolnej, zgodnej z ochroną środowiska naturalnego. Według zasad dobrej kultury rolnej trzeba brać pod uwagę: właściwe warunki glebowe i klimatyczne, istniejące systemy gospodarowania, wykorzystanie

${ }^{23}$ Dodatkowe warunki, jakie należało spełnić, to: położenie nie dalej niż $50 \mathrm{~m}$ od drogi publicznej i 50 m od granicy najbliższej działki budowlanej; nie stanowią większej powierzchni niż 0,5 ha.

${ }^{24}$ A. Świtalska, Ochrona gruntów rolnych..., dz. cyt. s. 241-256.

${ }^{25}$ Ustawa z dnia 14 kwietnia 2016 r. o wstrzymaniu sprzedaży nieruchomości Zasobu Własności Rolnej Skarbu Państwa oraz zmianie niektórych ustaw, Dz.U. z 2016 r., poz. 585.

${ }^{26}$ S. Urban, Rola ziemi $w$ rolnictwie zrównoważonym a aktualne jej zasoby $w$ Polsce, „Acta Agraria et Silvestria. Series Agraria, Sekcja Ekonomiczna” 2003, t. XL. 
gruntów, zmianowanie upraw, metody uprawy roli, a także struktury gospodarstw $^{27}$.

W ramach II filara WPR podejmowane są działania związane z rozwojem obszarów wiejskich. Drugi filar WPR w kolejnych okresach budżetowania (2000-2006; 2007-2013 i obecnego 2014-2020) Planu Rozwoju Obszarów Wiejskich zakłada wiele działań, które pośrednio lub bezpośrednio miały i mają na względzie dobre gospodarowanie gruntami rolnymi. Do takich działań można zaliczyć: scalanie gruntów rolnych, których celem było: stworzenie korzystniejszych warunków gospodarowania, utworzenie zwartych kompleksów gruntów, poprawę struktury obszarowej oraz utrzymanie walorów środowiska naturalnego. Do istotnych działań związanych z poprawą warunków gospodarowania należy zaliczyć wprowadzony w 1975 roku system wsparcia rolnictwa w górach i innych obszarach o niekorzystnych warunkach do produkcji rolnej, który chronił ziemię rolną przed wypadaniem z użytkowania rolniczego. Celem wsparcia, wprowadzonego dyrektywą EWG 268/75 było przede wszystkim zapewnienie kontynuacji działalności rolniczej i zachowanie żywotności społeczno-ekonomicznej wsi. Ustalono w niej granice obszaru objętego interwencją na rzecz rolnictwa strukturalnie i naturalnie upośledzonego i po raz pierwszy zdecydowano się na kompensowanie strat wynikających z upośledzenia, głównie dopłat rekompensujących zmniejszoną rentę gruntową na tych obszarach.

Za priorytety polityki wspierania rozwoju obszarów wiejskich w latach 2007-2013 przyjęto wspieranie gospodarowania gruntami, stymulowanie restrukturyzacji, rozwoju i wdrażania innowacji w rolnictwie oraz leśnictwie, różnicowanie działalności gospodarczej prowadzonej na terenach wiejskich. Celem przyjętej polityki ma być poprawa jakości życia, stanu środowiska, konkurencyjności rolnictwa i leśnictwa.

${ }^{27}$ Rozporządzenie Rady (WE) nr 1782/2003 z dnia 29 września 2003 r. ustanawiające wspólne zasady dla systemów wsparcia bezpośredniego w ramach WPR, Dz.U. L 270 z 21.10.2003 r., z późn. zm. 


\section{Podsumowanie}

Grunty rolne, jako ważny i ograniczony zasób produkcyjny, środowiskowy i kulturowy, powinne być obejmowane szczególną ochroną ze względu na ich doniosłe znaczenie dla bezpieczeństwa żywnościowego, równowagi ekologicznej i jakości życia społecznego. Ubytek ziemi użytkowanej rolniczo w Polsce jest procesem ciągłym i charakteryzuje go różne natężenie. W procesie wyłączania gruntów rolnych na cele nierolnicze wyraźnie dominuje wzrost ich powierzchni, przeznaczanej na tereny osiedlowe. Niepokojącym zjawiskiem jest duży udział użytków rolnych wysokiej jakości (klasy I-III) w ogólnej powierzchni wyłączanych gruntów rolnych na cele nierolnicze. Zatem, ziemia jako dobro o niepowtarzalnej wartości, winna być bezwzględnie objęta większym, niż dotychczas szacunkiem i ochroną.

W analizowanym okresie pozytywnym procesem było zmniejszenie powierzchni gruntów ugorowanych, do czego przyczyniło się wprowadzenie płatności bezpośrednich do polskiego rolnictwa. Ważny, korzystny wpływ na kształtowanie struktury użytkowania ziemi na cele rolnicze i nierolnicze już wywarła i może dalej wywierać Wspólna Polityka Rolna Unii Europejskiej. Także, efektywne dla ochrony gruntów rolnych przed nadmiernym przekazywaniem ich na cele nierolnicze okazały się kolejne akty prawne, wdrożone w ostatnich kilkudziesięciu latach. 